\title{
Geochemical Characterization of Novokrivoyrog Metavolcanics: Tectonic Implications and Relationship with the Early Proterozoic Banded Iron Formation (BIF) of Krivoy Rog in Ukraine
}

\author{
Germain M. M. Mboudou ${ }^{1 *}$, Cheo E. Suh ${ }^{1}$, George T. Mafany ${ }^{2}$ \\ ${ }^{1}$ Economic Geology Unit, Department of Geology and Environmental Science, University of Buea, Buea, Cameroon \\ ${ }^{2}$ Institute of Mining and Geological Research, Regional Delegation of Scientific Research and Innovation, \\ South West Region, Buea, Cameroon \\ Email: * mboudougermain@yahoo.f
}

Received February 8, 2012; revised March 13, 2012; accepted April 15, 2012

\begin{abstract}
The geochemical characterization of Novokrivoyrog metavolcanics $(2.2 \mathrm{Ga})$ and Krivoy Rog iron ores $(1.8 \mathrm{Ga})$ in Ukraine represent an important tool for the understanding of their genesis and tectono-magmatic evolution. The petrological classification of the metavolcanics on $\mathrm{SiO}_{2} /\left(\mathrm{Zr}-\mathrm{TiO}_{2}\right)$ and $\left(\mathrm{Zr}-\mathrm{TiO}_{2}\right) /(\mathrm{Nb} / \mathrm{Y})$ Harker-type diagrams shows similarities to subalkaline andesitic basalts. An additional classification of the basalts on TAS $\left(\mathrm{Na}_{2} \mathrm{O}+\mathrm{K}_{2} \mathrm{O} / \mathrm{SiO}_{2}\right)$ and AFM (FeO-MgO- $\left.\mathrm{Na}_{2} \mathrm{O}+\mathrm{K}_{2} \mathrm{O}\right)$ diagrams exhibits a variable magmatic character from calc-alkaline to tholeiitic. The distribution of High Field Strength Elements, (HSFE: Ti, Zr, Y, Hf, Nb), V, Cr, and Rare Earth Elements (REE) in most of the rocks is close to calc-alkaline basalts $(\mathrm{CAB})$ and can be compared to Precambrian mid-ocean ridge basalts $(\mathrm{MORB})$ where high thermal $\left(>250^{\circ} \mathrm{C}\right)$ basaltic alteration is intensive under $\mathrm{pH}$ conditions between 2 and 4 . These contributed to the deposition of the Krivoy Rog BIFs. Indeed REE distribution patterns of the BIFs suggest that they can be subdivided into shales and shaly BIFs (rich in LREEs since their detrital and clastic inputs are much higher) with $(\mathrm{La} / \mathrm{Yb}) \mathrm{N}>1$ as indication of clastic inputs; chert and cherty BIFs showing positive Eu anomaly with $(\mathrm{La} / \mathrm{Yb}) \mathrm{N}<1$ are similar to REE patterns of mixed hydrothermal fluids and seawater; alkaline altered BIFs whose $(\mathrm{La} / \mathrm{Yb}) \mathrm{N}$ ratio is $>1$ emphasizes post-depositional effects related to the enrichment of light REEs over heavy REEs with a positive Eu anomaly. The distribution of REE patterns of Krivoy Rog BIFs can finally be compared to Precambrian iron formations of mixed submarine hydrothermal fluids and seawater origin which correspond to the MORB signature of the Novokrivoyrog metavolcanics.
\end{abstract}

Keywords: BIF; Geochemistry; Ukraine; REE; Metavolcanics

\section{Introduction}

Sedimentary iron ores are found in Precambrian geological sequences as simple iron formations (IFs) or banded iron formations (BIFs) associated with green stones or metavolcanic rocks. The mineralogical composition of such formations usually presents low- to medium-grade metamorphic associations that do not reflect primary chemical sedimentation. The geochemical characterization of metavolcanic rocks of Novokrivoyrog may answer the questions whether they resulted from rifting processes or they originated from a subduction related volcanic arc or what could be their contribution to the deposition of Krivoy Rog banded iron formations (BIFs). On

${ }^{*}$ Corresponding author. the other hand the distribution of Rare Earth Elements (REE) is rarely influenced by recrystallization processes related to metamorphic activity. REEs can thus be used as geochemical indicators to provide information on the changing conditions of terrestrial hydrosphere, lithosphere, and atmosphere systems that might have affected the formation of Precambrian BIFs [1-3]. The different fractionation properties of intermediate (MREEs), light (LREES), heavy (HREEs) Rare Earth Elements combined with redox sensitive elements such as $\mathrm{Ce}$ and $\mathrm{Eu}$ when showing positive or negative anomalies may give an indication to the physicochemical environment of REEs partitioning, the sources, the mobilization and precipitation of iron. These aspects are considered in this article with regards to the Krivoy Rog iron formations in Ukraine. 


\section{Geological and Tectonic Setting of the Krivoy Rog Iron Formations}

The Krivoy Rog Krementschug zone, in the central part of the Ukrainian Shield, represents an Early Proterozoic submeridional deep fault system [4], which was formed through Archean rifting processes between two crustal units: the easterly located Archean Dniepropetrovsk microplate (built by the Konka-Verkhotsev Archean greenstone assemblages, amphibolites, schist and quartzites of the Awul Group) and the westerly Early Proterozoic volcano-sedimentary block Ingul-Inguletsk (Figure 1). The Krivoy Rog Krementschug zone hosts the early Proterozoic Krivoy Rog Series and has a linear structure. This structure is probably the result of several deformation processes that are related to the formation of four major fault zones. The early Proterozoic Krivoy Rog Series occur discordantly on the Archean basement and are made up of five suites: The 2.2 Ga-old Novokrivorog suite with a thickness of about $2000 \mathrm{~m}$ is made up of metavolcanic rocks in its lower part and metasandstones and metaconglomerates at the top. Novokrivoyrog metavolcanic rocks were thought to belong to Dniepropetrovsk Archean assemblages [5] although many authors associate them with early Proterozoic formations. Metasandstones and metaconglomerates of the Skelevatsk suite $(50-300 \mathrm{~m})$ occur discordant over the Novokrivoyrog upper sequence. The banded iron formation is composed of seven $\mathrm{Fe}$ poor schist and quartzite layers alternating with Fe-rich jaspillite horizons. The high metamorphic grade in the upper sequence (amphiboliteepidote facies), where biotite-epidote-garnet and cummingtonite mineral associations are found, contains about $65 \% \mathrm{Fe}$. The lower sequence is $\mathrm{Fe}$ poor with less than $40 \% \mathrm{Fe}$, and is of green schist metamorphic facies.

\subsection{The Krivoy Rog (Sakssagan) BIF}

The Sakssagan BIF is close to $1.8 \mathrm{Ga}$ old and 1300 to $1400 \mathrm{~m}$ thick. It is located within the submeridional striking Krivoy Rog basin and forms the Sakssagan monocline [6]. The Sakssagan BIF (Figure 2) lies discordantly between the young terrigenous formations of Gdanzev-Gleevatst (700 - $800 \mathrm{~m})$ and the old Skelevastk metaconglomerates. It can be subdivided into seven alternating quartzite and schist horizons as a result of facies changing during sedimentation [6]. These horizons are grouped in three metamorphic sequences where Fepoor quartzite and $\mathrm{Fe}$-rich jaspilite are found in association with schists. The mineralogical composition of Sakssagan BIF is marked by the occurrence of quartz-biotitechlorite schist and quartz-biotite-amphibolitic quartzites. Quartz-biotite-epidote quartzite and schist with little garnet indicate an epidote-amphibolite meta-morphic facies
[4]. However the profile of Krivoy Rog BIF exhibits three different iron ore units (Figure 2): a lower iron ore unit which is composed of two quartzite and two schist horizons associated with carbonate rocks; a medium unit which presents two schist horizons of green schist metamorphic grade separated by a considerable quartzite layer, and; an upper iron ore unit which is mostly of greenschist metamorphic grade although indications for higher metamorphic facies are available through rare occurrences of quartz-biotite-epidote and quartz-biotite-cummingtonite-garnet associations. Jaspilite, quartzite and schist contain $40 \%$ to $70 \% \mathrm{Fe}$.

\subsection{Petrographic Features of Novokrivorog Metavolcanics}

The area of study is made up of low grade (greenschist to amphibolite facies) amphibolitic rocks that are mainly composed of fine-grained syngenetic hornblende and plagioclase which derived from primary melting material. Accessory components include quartz, apatite and biotite. An association of altered minerals (probably recrystallisation of hornblende in siderite, as well as sericitisation of plagioclase) may indicate a secondary mineral paragenesis.

\section{Sampling and Geochemical Analysis}

Systematic sampling of outcrops and cores was carried out to cover the area of occurrence of the Novokrivoyrog metavolcanic rocks and the iron ores. Samples from the seven iron ore horizons of Krivoy Rog BIFs were equally collected. A total of 26 metavolcanic samples and 15 greenschist metamorphic grade ore samples $\left(<40 \% \mathrm{Fe}_{2} \mathrm{O}_{3}\right)$ were selected and prepared in the Geochemical Laboratory of the Technical University of Berlin (Germany) for major and trace elements analysis by wavelength dispersive X-rays fluorescence (PHILIPS PW 1450) method. Programs "Powder 1" (for powder pellets) and Oxiquant (for fusion pellets) were used for analytical quality control. On the other hand REEs, Scandium (Sc), Yttrium (Y) and Hafnium (Hf) were determined by inductively coupled plasma atomic emission spectrometry (ICP-AES: 5500 PERKIN ELMER). REE patterns of Novokrivoyrog metavolcanics were chondrite-normalised while REE patterns of BIFs were normalized against the Post Archean Australian Shales (PAAS) [7].

\section{Geochemistry of Metavolcanic Rocks}

\subsection{Major Elements and Trace Elements}

The full geochemical data for the samples analysed are given in Table 1. From the plot of $\mathrm{SiO}_{2}$ versus $\left(\mathrm{Zr} / \mathrm{TiO}_{2}\right)$ and $\left(\mathrm{Zr} / \mathrm{TiO}_{2}\right)$ versus $\mathrm{Nb} / \mathrm{Y}$ diagrams [8] (Figures 3(a) 


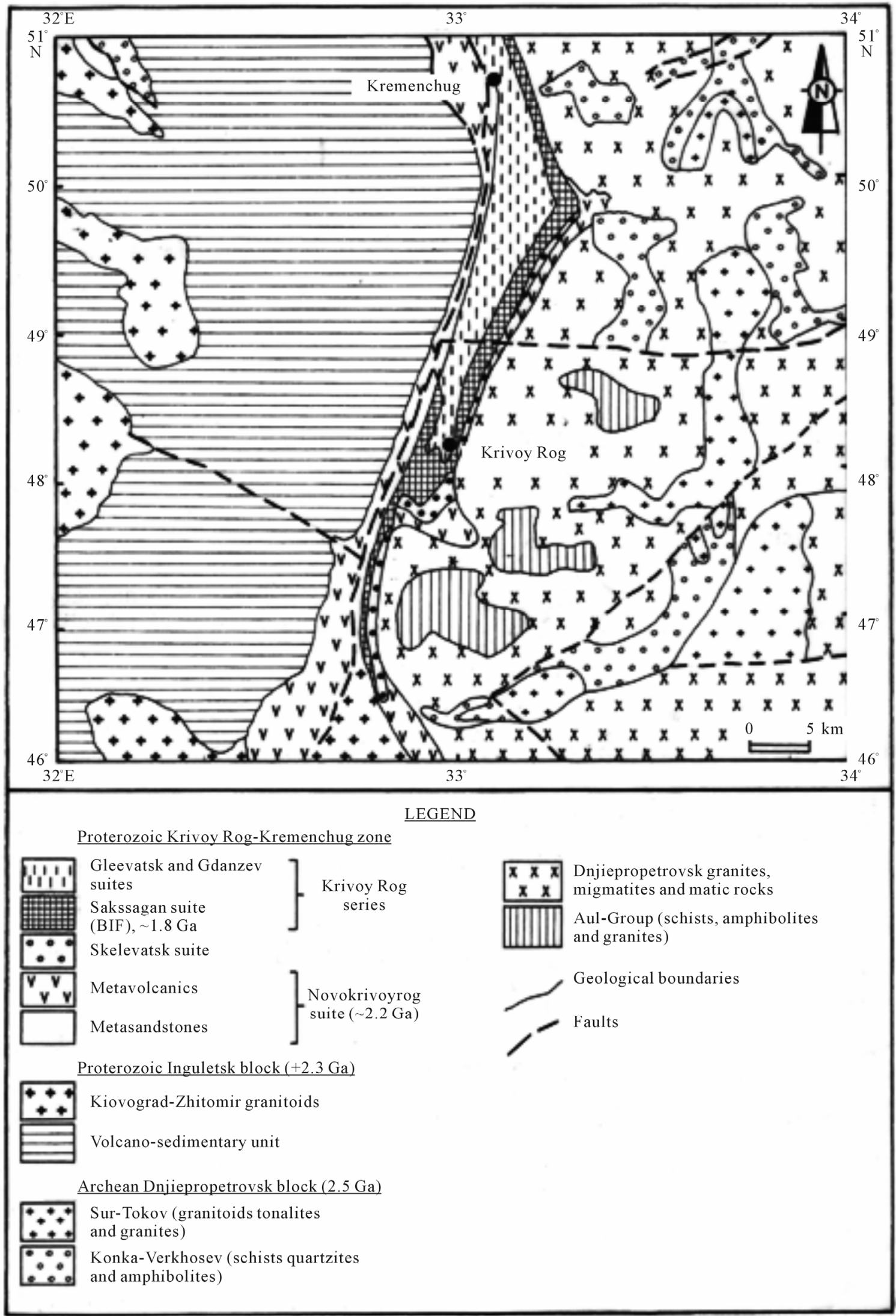

Figure 1. Sketch geological map of Krivoy Rog basin modified after Storchak (1984). 


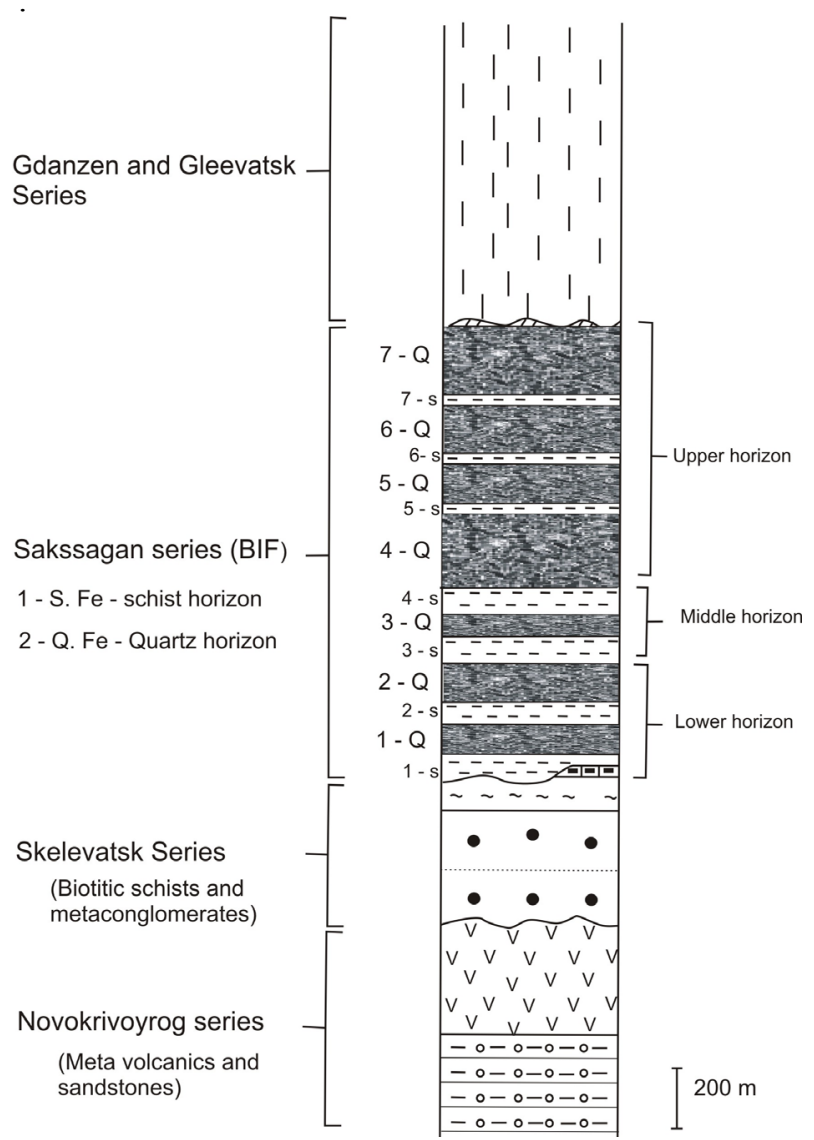

Figure 2. Schematic lithostratigraphic profile of the Krivoy Rog series showing the layered structure if the Sakssagan BIFs.

and (b)), most of the samples are similar to subalkaline andesitic basalts. Few samples from Litmanovsk (southern part of Krivoy Rog basin) also show similarities to trachyte/nepheline basalts. The subalkaline andesitic basalts were plotted on the Total Alkali Silica (TAS) diagram and Alkaline Silica (AFM) diagram (FeO-MgO $\mathrm{Na}_{2} \mathrm{O}+\mathrm{K}_{2} \mathrm{O}$ ) of [9] for additional classification. The samples predominantly have a subalkaline affinity (Figure 4(a)) and represent a variable magmatic calc alkaline (Figure 4(b)) to tholeiitic character [10]. Tectonic-magmatic classification of the metavolcanic rocks was carried out on the basis of the distribution of High Field Strength Elements, (HFSE: Ti, Zr, Y, Nb), Cr and V. The plot of $\mathrm{Ti} / \mathrm{Zr} / \mathrm{Y}$ and $\mathrm{Ti} / \mathrm{Zr}$, (Figures 5(a) and (b)) of [11] indicate that most of the samples are closer to the calcalkaline basalts field (CAB), and few samples are related to within plate basalts (WPB) and ocean floor basalts (OFB). The complete sequence of Novokrivoyrog metavolcanic rocks is also plotted on the $\mathrm{Ti} / \mathrm{V}$ diagram (Figure 6) after [12]. Most of the samples are similar to midocean ridge basalts (MORB). Few samples from North Sakssagan (northern edge of the basin) ore field are similar to ocean island basalts (OIB).

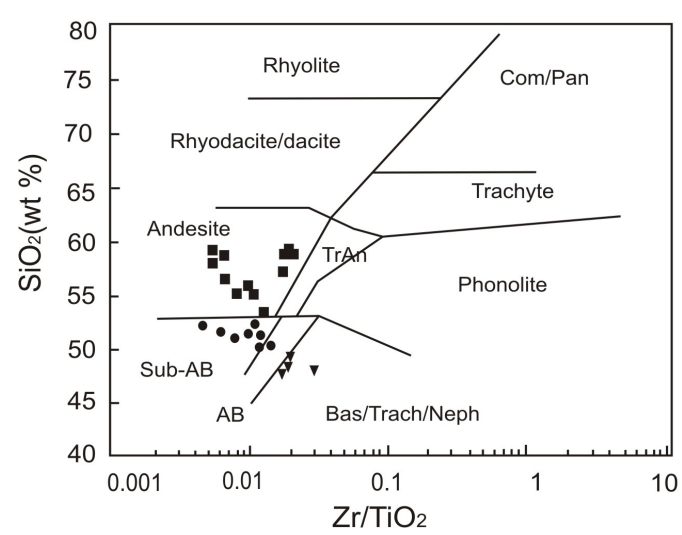

(a)

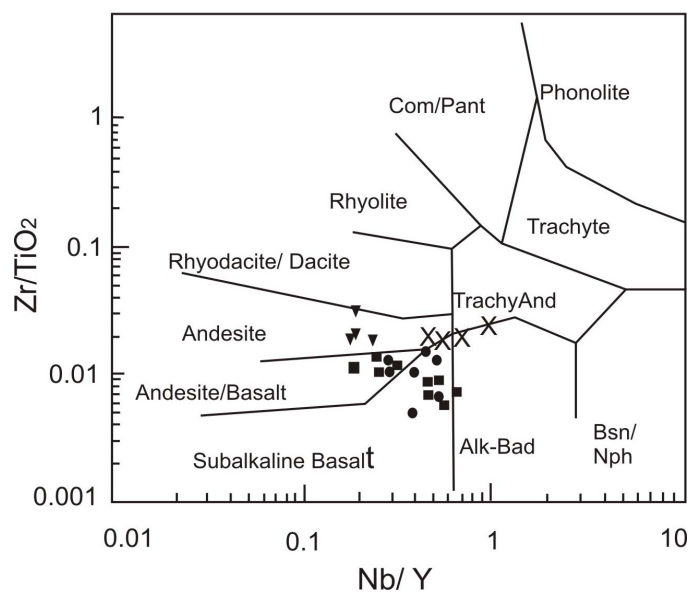

(b)

Figure 3. Petrological classification of Novokrivoyrog metavolcanics after Winchester and Floyd (1977): (a) and (b) show that Novokrivoyrog metavolcanics are similar to sub alkaline andesitic basalts. - Samples collected from Saksagan ore field (Central part of Krivoy Rog); $\nabla$ Samples collected from Litmanovsk ore field (Southern part of Krivoy Rog); $\star$ Samples collected from Saksagan ore field (Northern part of Krivoy Rog); • Samples collected from Inguletsk ore field (Westhern part of Krivoy Rog).

\subsection{Rare Earth Elements}

Chondrite-normalised REE patterns of the Novokrivoyrog metavolcanic rocks after [7] show neither Ce nor Eu anomalies (Figure 7) and have similar features like calc alkaline series from active continental margin or island arc tholeiitic formations [13]. Light rare earth elements (LREE) are dominant compared to fractionated heavy rare earth elements (HREE). REE distribution patterns of Krivoy Rog BIFs reveal three groups corresponding to different ore types: shales and shaly BIFs, alkaline-altered BIFs, cherts and cherty BIFs. These groups are characterized by different europium $(\mathrm{Eu})$ and Cerium $(\mathrm{Ce})$ anomalies as a result of changes in environmental conditions during and after sedimentation.

The REE patterns of shales and shaly BIFs (Figure 


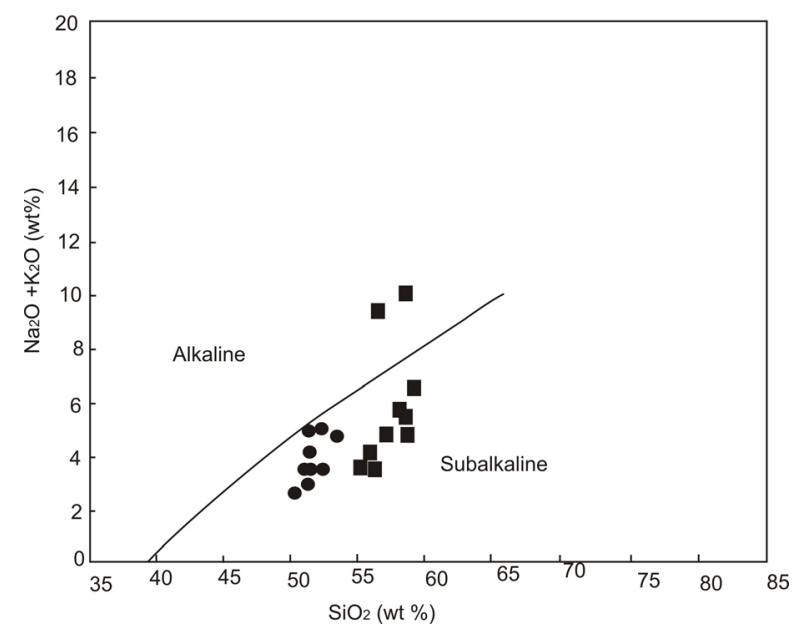

(a)

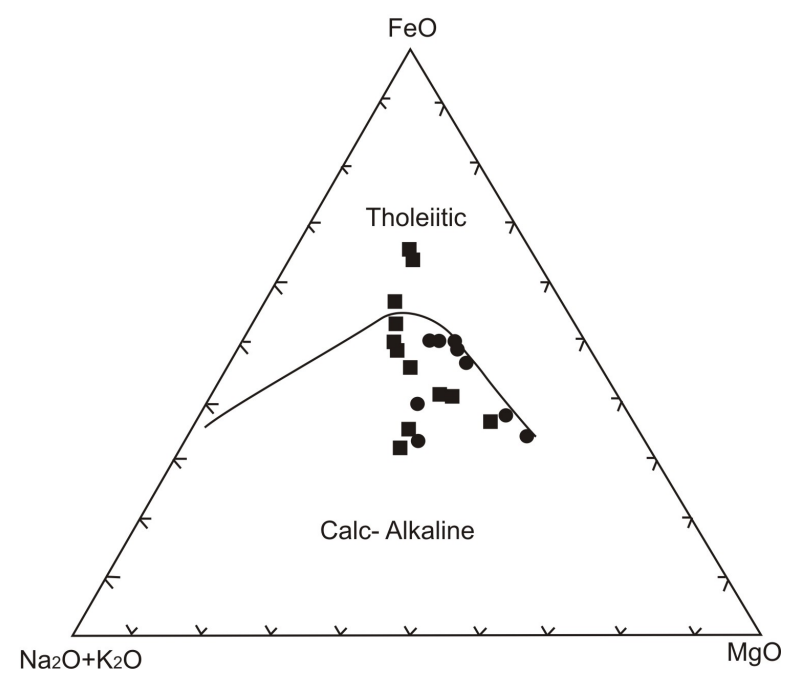

(b)

Figure 4. Differenciation of tholeitic and calc alkaline trends of Novokrivoyrog metavolcanics after Irvine and Baragar (1971): (a) Diagram showing sub alkaline character of Novokrivoyrog metavolcanics; (b) AFM diagram illustrating the calc alkaline trend of Novkrivoyrog metavolcanics (symbols same as in Figure 3).

8(a)) show a pattern of depletion of HREEs over LREEs. The positive $\mathrm{Eu}$ anomaly of shales and shaly BIFs indicates reducing depositional conditions, while the $\mathrm{Ce}$ anomaly is absent. The slight difference in REEs patterns of shales (sample Kr 32) and shaly BIFs (samples Kr 33a and $\mathrm{Kr} 7$ ) resulted from non conformity in detrital and clastic supplies in both cases since shales were formed under more clastic and detrital influence [14]. Similarities of the above mentioned REE patterns to Precambrian shales after [7] are confirmed by the ratio $(\mathrm{La} / \mathrm{Yb}) \mathrm{N}>1$ [15] as shown in Table 1.

In the alkali-altered BIFs the positive Eu anomaly (Figure 8(b)) confirms the reducing conditions prevailing during the formation of worldwide Precambrian iron

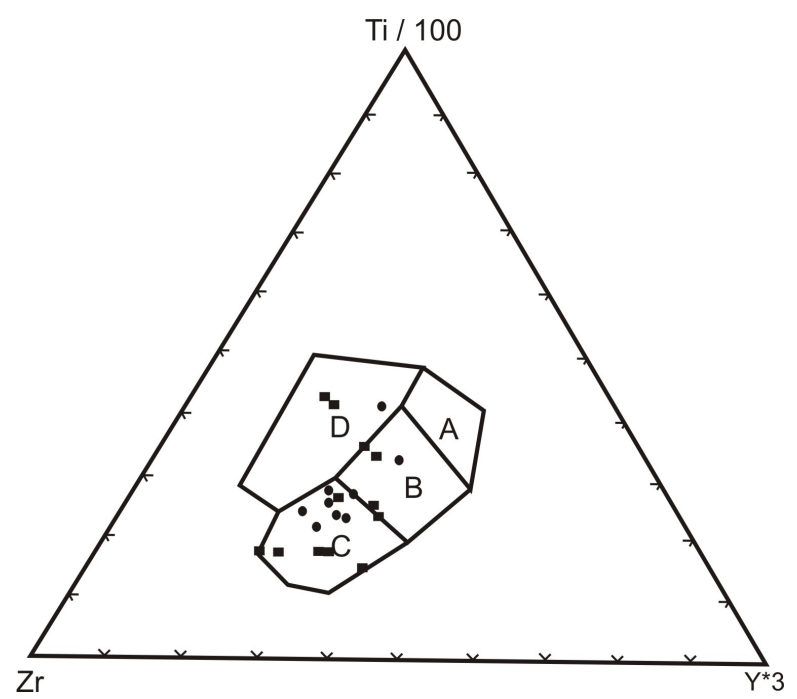

(a)

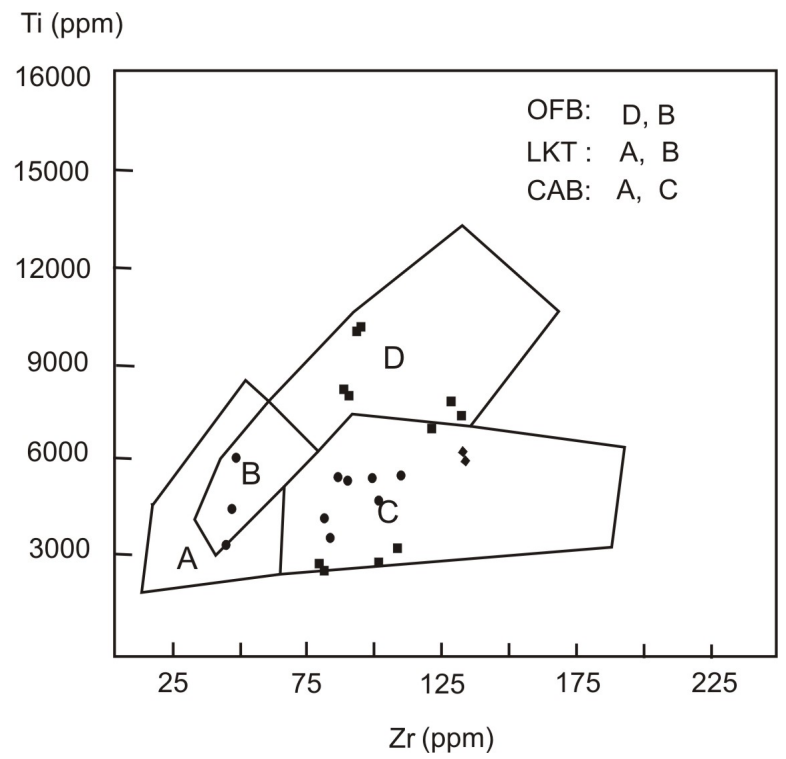

(b)

Figure 5. Tectonic magmatic classification of Novokrivoyrog metavolcanics after Pearce and Cann (1973): (a) Ti/Zr/ Y diagram with mostly CAB signatures; (b) Ti/Zr diagram showing few WPB and OFB signatures (symbols same as in Figure 3).

ores. However, the abundance of HREEs compared to LREEs may indicate fractionation effects of light REEs over heavy REEs. Since no Ce anomaly (see samples $\mathrm{Kr}$ 76 and kr 26 in Figure 4) has been found in Precambrian sediments [3], it is thought that such an anomaly may instead reflect the abundance of other Ce species in submarine hydrothermal fluids. ( $\mathrm{La} / \mathrm{Yb}) \mathrm{N}<1$ for the alkaline-altered BIFs (Table 1) is considered to be an indication of REEs from mixed hydrothermal fluid and seawater [16].

REE patterns of chert and cherty BIFs (Figure 8(c)) 


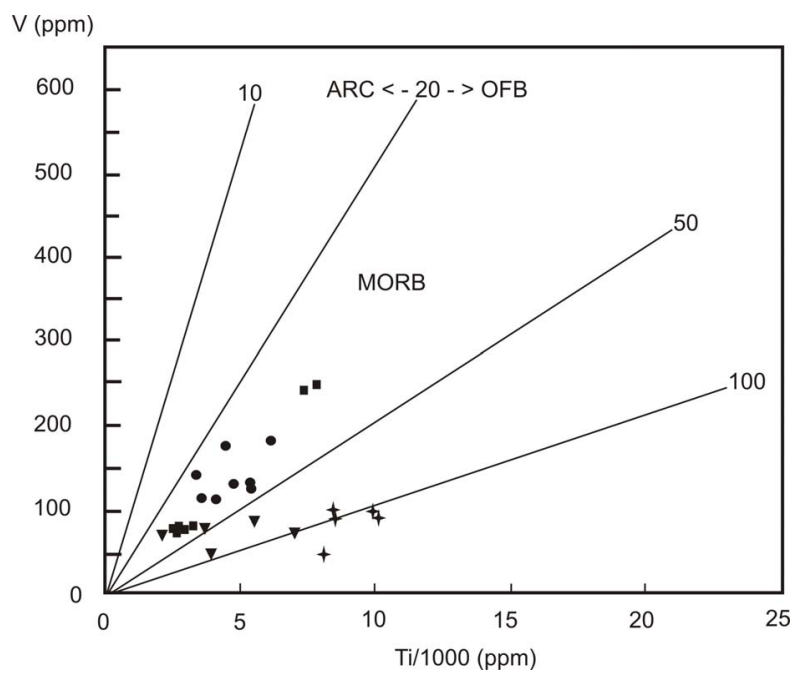

Figure 6. V/Zr diagram after Shervais (1982). Novokrivoyrog metavolcanics dominantly plot in MORB field (symbols same as in Figure 3).

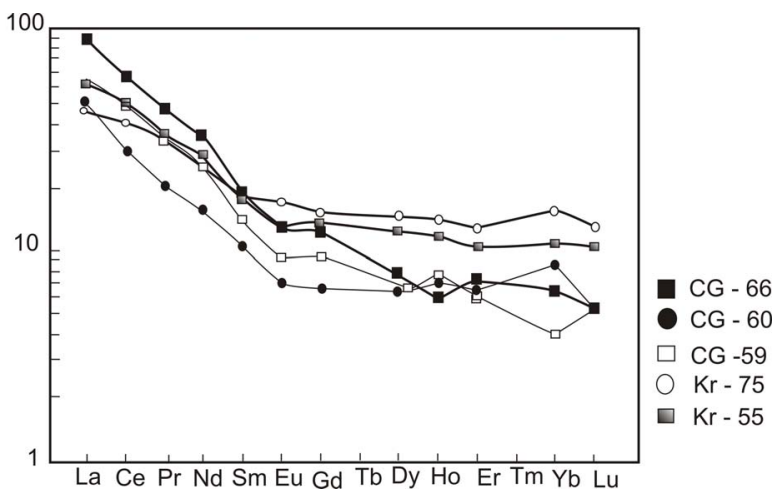

Figure 7. Chondrite normalized REE patterns of selected Novokrivoyrog metavolcanic.

show positive Eu anomalies and much more abundant HREEs over LREEs which can also be compared to REE patterns of mixed hydrothermal fluids and seawater [17]. In addition, the REE patterns above also exhibit $(\mathrm{La} / \mathrm{Yb}) \mathrm{N}$ $<1[3]$.

\section{Discussion}

The major element data and petrographic features indicate that Novokrivoyrog amphibolitic rocks symbolize a varying magmatic trend from calc alkaline to tholeiitic character which might have taken place either within an island arc system (calc-alkaline signature), or in other tectonic setting (tholeiitic signature). Trace elements and REE data equally precise that Novokrivoyrog metavolcanics could be compared to midocean ridge basalts and ocean island basalts, since their geochemical characteristics indicate a bimodal volcanism where both calc-alkaline and tholeiitic sequences are available.

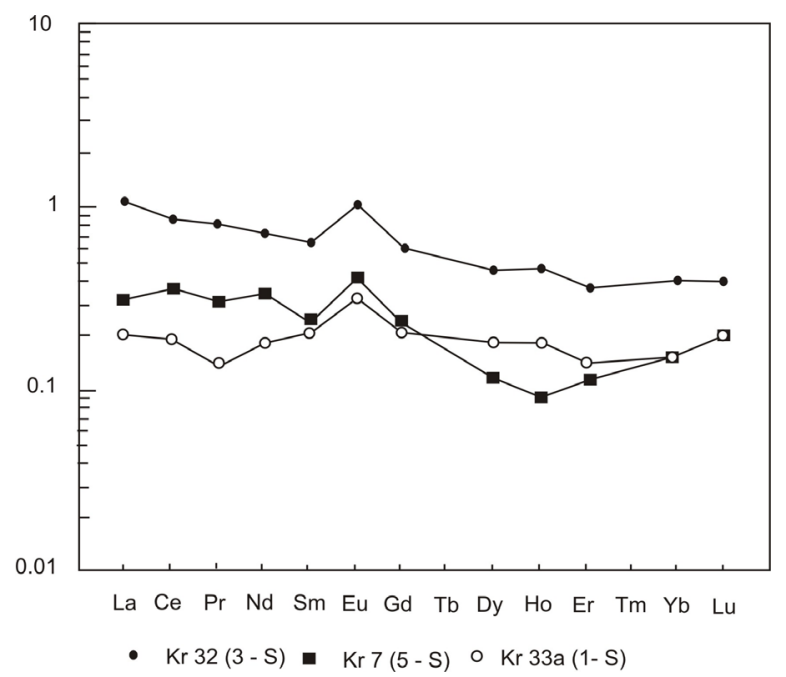

(a)

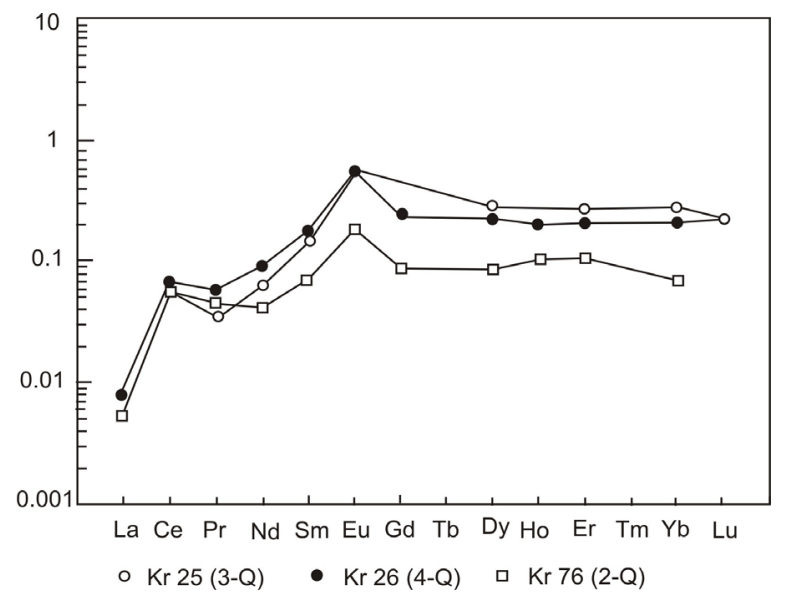

(b)

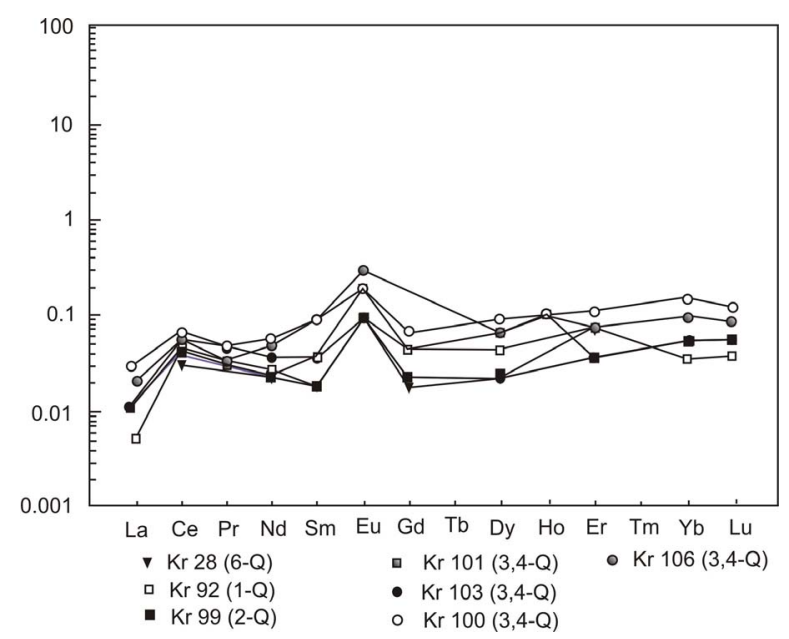

(c)

Figure 8. (a) Post Archean Australian Shale (PAAS) normalized REE patterns of Krivoy Rog BIF for shales and shaly BIFs; (b) and (c) Post Archean Australian Shale (PAAS) normalized REE patterns of Krivoy Rog BIF; (b) Alkali altered BIFs; (c) Cherts and cherty BIFs. 
Table 1. Rare earth elements abundances of different types of Krivoy Rog BIFs. Eu, Sm, and Yb ratios are highlighted.

\begin{tabular}{|c|c|c|c|c|c|c|c|c|c|c|c|}
\hline \multicolumn{4}{|c|}{ Element Shales and Shaly BIFs } & \multicolumn{4}{|c|}{ Alkaline Alterated BIFs } & \multicolumn{4}{|c|}{ Cherts and Cherty BIFs } \\
\hline & Kr 32 & $\mathrm{Kr} 7$ & $\mathrm{Kr} 33 \mathrm{a}$ & Kr 26 & $\operatorname{Kr} 25$ & $\mathrm{Kr} 76$ & Kr 105 & Kr 106 & Kr 103 & $\mathrm{Kr} 28$ & $\mathrm{Kr} 92$ \\
\hline $\mathrm{La}$ & 34.00 & 10.00 & 6.50 & 0.30 & $<0.20$ & 0.20 & $<0.20$ & 0.80 & $<0.20$ & $<0.20$ & 0.20 \\
\hline $\mathrm{Ce}$ & 63.00 & 26.00 & 14.00 & 5.20 & 4.30 & 4.30 & 5.10 & 5.00 & 4.30 & 2.00 & 3.80 \\
\hline $\operatorname{Pr}$ & 6.40 & 2.40 & 1.10 & 0.50 & 0.30 & 0.40 & 0.40 & 0.10 & 0.40 & $<0.10$ & 0.30 \\
\hline $\mathrm{Nd}$ & 24.00 & 11.00 & 6.00 & 3.10 & 2.10 & 1.40 & 1.90 & 1.60 & 1.20 & $<0.50$ & 0.90 \\
\hline $\mathrm{Sm}$ & 3.70 & 1.30 & 1.20 & 1.00 & 0.80 & 0.40 & 0.50 & 0.50 & 0.20 & 0.20 & 0.20 \\
\hline $\mathrm{Eu}$ & 1.30 & 0.50 & 0.40 & 0.60 & 0.60 & 0.20 & 0.20 & 0.30 & 0.10 & 0.10 & 0.10 \\
\hline $\mathrm{Gd}$ & 3.20 & 0.20 & 1.10 & 1.10 & 1.10 & 0.40 & $<0.10$ & $<0,10$ & 0.20 & 0.60 & 0.20 \\
\hline Dy & 2.70 & 0.70 & 1.10 & 1.10 & 1.30 & 0.30 & 0.40 & 0.30 & 0.20 & 0.60 & 0.20 \\
\hline Ho & 0.50 & 0.10 & 0.20 & 0.20 & 0.40 & 0.10 & $<0.10$ & 0.10 & 0.10 & 0.20 & $<0.10$ \\
\hline Er & 1.30 & 0.40 & 0.60 & 0.50 & 0.80 & 0.30 & 0.30 & 0.20 & 0.10 & 0.60 & 0.20 \\
\hline $\mathrm{Yb}$ & 1.30 & 0.50 & 0.50 & 0.50 & 0.80 & 0.20 & 0.20 & $<0.10$ & $<0.10$ & 0.80 & 0.10 \\
\hline $\mathrm{Lu}$ & 0.20 & 0.10 & 0.10 & 0.10 & 0.10 & 0.50 & 0.50 & $<0.10$ & $<0.10$ & 0.20 & $<0.10$ \\
\hline $\mathrm{Hf}$ & 2.50 & 1.40 & 0.30 & 0.50 & 0.40 & 0.20 & 1.40 & $<0.10$ & 0.10 & $<0.10$ & 0.20 \\
\hline LREE & 131.10 & 50.70 & 28.80 & 10.10 & 7.50 & 6.70 & 7.90 & 8.00 & 6.10 & 2.20 & 5.40 \\
\hline HREE & 9.20 & 2.00 & 3.50 & 3.40 & 4.50 & 1.80 & 1.40 & 0.60 & 0.60 & 3.00 & 0.70 \\
\hline$\sum \mathrm{REE}$ & 140.30 & 52.70 & 32.30 & 13.50 & 12.00 & 8.50 & 9.30 & 8.60 & 6.70 & 5.20 & 6.10 \\
\hline$(\mathrm{Eu} / \mathrm{Sm}) \mathrm{C}_{\mathrm{N}}$ & 1.01 & 1.10 & 3.49 & 1.72 & 2.16 & 1.44 & 1.15 & 1.72 & 1.12 & 1.45 & 1.03 \\
\hline$(\mathrm{Sm} / \mathrm{Yb}) \mathrm{C}_{\mathrm{N}}$ & 2.97 & 2.71 & 3.96 & 1,73 & 3.01 & 2.16 & 2.71 & - & - & 3.00 & 3.17 \\
\hline$(\mathrm{Eu} / \mathrm{Sm}) \mathrm{S}_{\mathrm{N}}$ & 1.79 & 2.00 & 1.76 & 3.05 & 3.92 & 2.57 & 2.01 & 3.10 & 2.63 & 3.00 & 3.17 \\
\hline$(\mathrm{Sm} / \mathrm{Yb}) \mathrm{S}_{\mathrm{N}}$ & 1.43 & 1.35 & 1.23 & 1.06 & 0.18 & 1.02 & 1.28 & - & - & 0.12 & 1.02 \\
\hline
\end{tabular}

$\mathrm{C}_{\mathrm{N}}$ : Chondrite normalization after Taylor and McLenan (1985); $\mathrm{S}_{\mathrm{N}}$ : PAAS normalization after Taylor and McLenan (1985).

\section{Genetic implications of Novokrivoyrog Metavolcanics and Krivoy Rog BIFs}

Three main hypotheses about the genesis of Precambrian iron formations have been propounded. The removal of $\mathrm{Fe}$ and $\mathrm{SiO}_{2}$ from detrital sediments due to weathering in a reducing deep marine environment may be the source of iron and silica [18]. [19] attributed the precipitation of huge amounts of iron and silica in a marine setting to the deposition of weathered transported materials from inland. However the importance of hydrothermal activity in the formation of BIFs mentioned by [1] fits better into this context. This hypothesis may find an answer in the Novokrivoyrog metavolcanics comparable to Midocean Ridge Basalts (MORB) as a major source for $\mathrm{SiO}_{2}$ and Fe after [20].

The positive Eu anomaly of shales and shaly BIFs, cherts and cherty BIFs including alkaline-altered BIFs of Krivoy Rog Precambrian banded iron ores points to high thermal basaltic alteration $[21,22]$, probably linked to the
Novokrivoyrog metavolcanics. $(\mathrm{La} / \mathrm{Yb}) \mathrm{N}<1$ and the enrichment of light upon heavy REEs equally support the hydrothermal hypothesis of [1]. In fact much intensive hydrothermal activity could have taken place within mid ocean ridges (MOR) during Precambrian times than in recent oceanic ridges. These high thermal fluids $\left(>250^{\circ} \mathrm{C}\right)$ carried along huge amounts of $\mathrm{Fe}$ and $\mathrm{SiO}_{2}$ that were deposited at $\mathrm{pH}$ varying between 2 and 4 [23].

The positive Eu anomaly of REE patterns of Krivoy Rog BIFs also indicate that hydrothermal submarine fluids probably mixed with sea water [1]: $\mathrm{Fe}^{2+}$ and $\mathrm{Si}^{2+}$ rich colloidal hydrothermal solutions transported from the Krivoy Rog epicontinental basin reacted with $\mathrm{Fe}$ and $\mathrm{SiO}_{2}$ dissolved in sea water as a closed system [15] with $\mathrm{pH}=8$ leading to the formation of sedimentary iron ores.

\section{Conclusions}

The most occurring calc alkaline metavolcanics in Novokrivoyrog seem to be related to middle ocean ridge 
basalts (MORB) and represent remnants of Paleo-Oceanic Crust. This situation might have played a leading role in the formation and precipitation of iron ores in the Krivoy Rog sedimentary basin. On the other hand, alkaline ocean island basalts (OIB) of Litmanovsk field in the south of Krivoy Rog and East Sakssagan field (north of Krivoy Rog) might indicate the boundaries of this basin.

The distribution and the interpretation of REEs of Proterozoic Krivoy BIFs indicate that iron ores originated from mixed submarine hydrothermal fluids and sea water. Submarine hydrothermal alteration linked to MORB (probable origin of Novokrivoyrog metavolcanics) and sea water are considered as major sources of $\mathrm{Fe}$ and $\mathrm{SiO}_{2}$ of the BIFs.

\section{Acknowledgements}

My thanks are addressed to Dr. Gunther Matheis and Pr Klaus German who have seriously contributed to the form of this work. A special thanks to Pr Michael Bau for his contribution to the analysis and interpretation of REE data.

\section{REFERENCES}

[1] M. Bau, N. J. Beukes and R. Romer, "Increase of Oxygen in the Earth Atmosphere and Hydrosphere between 2.5 and 2.4 Ga," Mineralogical Magazine, Vol. 62A, No. 1, 1998, pp. 127-128. doi:10.1180/minmag.1998.62A.1.67

[2] M. Bau, "Comment on Modelling of Rare Earth Element Participationing between Particles and Solution in Aquatic Environments by Y. Erel and E. M. Stolper," Geochimica et Cosmochimica Acta, Vol. 58, No. 20, 1994, pp. 45214523. doi:10.1016/0016-7037(94)90353-0

[3] M. Bau and P. Möller, "Präkambrische Chemisch-Sedimentäre Mineralisationen: Spiegel der Evolution von Lith-, Hydro-und Atmosphäre," Geowissenschaften, Vol. 12, 1994, pp. 333-336.

[4] A. V. Plotnikov, "Internal Structure and Development of the Krivoy Rog - Kremenchug Deep Fault System in the Krivoy Rog Area," Ph.D. Thesis, Mining Institute, Krivoy Rog, 1994.

[5] I. S. Parahnko, "Geolgical Formation and Stratigraphic Correlation of the Early Proterozoic of the Krivoyrojia," Report Habilatation Thesis, Mining Institute, Lviv, 1995.

[6] R. Y. Belevtsev, F. L. Zhukov and L. T. Savchenko "Accumulation Processes of Sediments in Krivoy Rog's IronSilica Formations, Based on Data of Carbon and Sulphurisotopic Investigations," The Journal of Geology, Vol. 44, 1994, pp. 94-102.

[7] S. R. Taylor and S. M. Mclennan, "The Continental Crust: Its Composition and Evolution," Blackwell Scientific Publications, Oxford, 1985.

[8] J. A. Winchester and P. A. Floyd, "Chemical Discrimination of Different Magma Series and Their Differentiation Products Using Immobile Element," Chemical Geology,
Vol. 20, 1977, pp. 325-343. doi:10.1016/0009-2541(77)90057-2

[9] T. N. Irvine and A. Baragar, "A Guide to the Chemical Classification of the Common Volcanic Rocks," Canadian Journal of Earth Sciences, Vol. 8, No. 5, 1971, pp. 523-548. doi:10.1139/e71-055

[10] A. Miyashiro, "Volcanic Rock Series in Island Arcs and Active Continental Margins," American Journal of Science, Vol. 274, No. 4, 1974, pp. 321-355. doi:10.2475/ajs.274.4.321

[11] J. A. Pearce and J. R. Cann, "Tectonic Settings of Basic Volcanic Rocks Using Trace Element Analyses," Earth and Planetary Science Letters, Vol. 19, No. 2, 1973, pp. 290-300. doi:10.1016/0012-821X(73)90129-5

[12] J. W. Shervais, "Ti-V Plots and the Petrogenesis of Modern Ophiolitic Lavas," Earth and Planetary Science Letters, Vol. 59, No. 1, 1982, pp. 101-118. doi:10.1016/0012-821X(82)90120-0

[13] P. Jakes and J. Gill, "Rare Earth Elements and the Island Arc Tholetiitic Series," Earth and Planetary Science Letters, Vol. 9, No. 1, 1970, pp. 17-28. doi:10.1016/0012-821X(70)90018-X

[14] M. A. Yaroschuk, B. A. Goriilsky, V. Onoprienko and E. A. Yaroschuk, "Geochemical Features of Iron-Silica Rocks in the Krivoyrojia as a Reflection of Physical and 10 Chemical Conditions during Their Sedimentation and Metamorphism," Geoisdatelstvo, Kiev, 1975.

[15] M. Bau, "Effects of Syn- and Post Depositional Process on the Rare Earth Elements Distribution in Precambrian Iron Formations," European Journal of Mineralogy, Vol. 5, No. 2, 1993, pp. 257-267.

[16] R. M. K. Khan and S. M. Naqvi, "Geology, Geochemistry and Genesis of BIF of Kushagi Schist Belt, Archean Dharwar Craton, India," Mineralium Deposita, Vol. 31, No. 1-2, 1996, pp. 123-133. doi:10.1007/BF00225403

[17] C. Klein and N. J. Beukes, "Geochemistry and Sedimentology of a Facies Transition from Limestone to Iron Formation Depsotion in the Early Proterozoic Transvaal Supergroup, South Africa," Economic Geology, Vol. 84, No. 7, 1989, pp. 1733-1774. doi:10.2113/gsecongeo.84.7.1733

[18] H. D. Holland, "The Chemical Evolution of the Atmosphere and the Oceans," Princeton University Press, Princeton, 1980, pp. 374-407.

[19] R. M. Garrels, "A Model for the Deposition of the Microbanded Iron Formations," American Journal of Science, Vol. 287, No. 2, 1987, pp. 81-106. doi:10.2475/ajs.287.2.81

[20] S. B. Jacobsen and P. M. Klose, "A Nd Isotopic Study of the Hamersley and Michipicoten Banded Iron Formations: the Source of REE and Fe in Archean Oceans," Earth and Planetary Science Letters, Vol. 87, No. 1-2, 1988, pp. 2944. doi:10.1016/0012-821X(88)90062-3

[21] R. N. Belevtsev, V. V. Rechetniak and M. I. Chernovsky "The Krivoy Rog-Kremenchug Ores Province," In: Precombrian Banded Iron Formations of the European Part of the USSR: Structure of Deposits and Ore-Provinces, Naukova Dumka, Kiev, 1989, pp. 7-18. 
[22] A. C. Campbell, M. R. Palmer, T. S. Bowers, G. P. Klinkhammer, J. M. Edmond, J. R. Lawrence, J. F. Casey, G. Thompson, S. Humphris, P. Rona and J. A. Karson "Chemistry of Hot Springs on the Mid-Atlantic Ridge," Nature, Vol. 355, No. 6190, 1988, pp. 514-519.

doi: $10.1038 / 335514 \mathrm{a} 0$
[23] C. Alibert and M. T. McCulloch, "Rare Earth Elements and Neodymium Isotopic Compositions of the Banded Iron Formation and Associated Shales of Hamersley Western Australia," Geochimica et Cosmochimica Acta, Vol. 57, No. 1, 1993, pp. 18-204. doi:10.1016/0016-7037(93)90478-F 
Appendix 1. Bulk-rock chemical analyses for major (wt\%), trace (ppm) and rare earth elements of Novokrivoyrog metavolcanics.

\begin{tabular}{|c|c|c|c|c|c|c|c|c|c|c|c|c|}
\hline Samples & $\mathrm{kr} 75$ & kr 55 & G1 & $\mathrm{G} 2$ & G3 & G4 & G5 & G6 & G7 & G9 & G30 & G75 \\
\hline \multicolumn{13}{|l|}{ wt $\%$} \\
\hline $\mathrm{SiO}_{2}$ & 55.80 & 59.03 & 51.30 & 52.36 & 49.14 & 50.16 & 56.46 & 50.23 & 56.01 & 55.01 & 51.52 & 52.20 \\
\hline $\mathrm{TiO}_{2}$ & 1.31 & 0.42 & 0.84 & 0.79 & 0.65 & 0.63 & 1.32 & 1.59 & 1.07 & 1.43 & 0.74 & 1.02 \\
\hline $\mathrm{Al}_{2} \mathrm{O}_{3}$ & 11.31 & 15.87 & 13.78 & 11.95 & 13.78 & 11.76 & 12.43 & 11.65 & 13.39 & 10.80 & 14.10 & 15.30 \\
\hline $\mathrm{Fe}_{2} \mathrm{O}_{3}$ & 12.03 & 9.22 & 12.83 & 12.97 & 11.83 & 12.40 & 11.02 & 10.06 & 7.50 & 11.00 & 10.15 & 10.01 \\
\hline $\mathrm{MnO}$ & 0.10 & 4.87 & 0.22 & 0.11 & 0.02 & 0.29 & 0.26 & 0.13 & 0.27 & 0.17 & 0.16 & 0.20 \\
\hline $\mathrm{MgO}$ & 3.64 & 2.85 & 6.80 & 7.6 & 6.81 & 7.04 & 4.46 & 7.30 & 6.70 & 9.22 & 6.87 & 5.90 \\
\hline $\mathrm{CaO}$ & 6.97 & 1.59 & 6.89 & 5.23 & 5.73 & 3.50 & 2.81 & 5.41 & 3.73 & 5.70 & 9.01 & 8.98 \\
\hline $\mathrm{Na}_{2} \mathrm{O}$ & 2.14 & 3.36 & 2.64 & 3.09 & 3.12 & 3,98 & 3.63 & 2.82 & 3.71 & 3.32 & 2.43 & 2.50 \\
\hline $\mathrm{K}_{2} \mathrm{O}$ & 1.43 & 0.12 & 0.31 & 1.65 & 1.01 & 1.32 & 1.68 & 0.87 & 2.00 & 3.76 & 1.10 & 0.96 \\
\hline $\mathrm{P}_{2} \mathrm{O}_{5}$ & 0.20 & 0.22 & 0.03 & 0.30 & 0.02 & 0.18 & 0.03 & 0.12 & 0.06 & 0.08 & 0.09 & 0.02 \\
\hline LOI\% & 5.02 & 2.44 & 4.32 & 4.02 & 7.81 & 8.71 & 5.84 & 9.78 & 4.40 & 2.49 & 3.81 & 2.81 \\
\hline Total & 99.99 & 99.99 & 99.96 & 99.97 & 99.82 & 99.98 & 99.97 & 99.96 & 99.98 & 99.98 & 99.99 & 99.98 \\
\hline \multicolumn{13}{|l|}{ ppm } \\
\hline $\mathrm{Cr}$ & 12 & 136 & 67 & 14 & 13 & 14 & 65 & 16 & 38 & 79 & 103 & 16 \\
\hline $\mathrm{Ni}$ & 42 & 108 & 324 & 127 & 332 & 321 & 479 & 57 & 125 & 237 & 41 & 39 \\
\hline Co & 290 & 20 & 14 & 11 & 11 & 9 & 46 & 65 & 8 & 5 & & 288 \\
\hline V & 245 & 79 & 79 & 130 & 130 & 38 & 47 & 114 & 96 & 89 & 180 & 239 \\
\hline $\mathrm{Pb}$ & 5 & 13 & 4 & 3 & 3 & 3 & & & & & & 6 \\
\hline $\mathrm{Zn}$ & 115 & 86 & 116 & 113 & 113 & 115 & 117 & 115 & 116 & 113 & 56 & 118 \\
\hline $\mathrm{Rb}$ & 33 & 130 & 21 & 27 & 27 & 26 & 31 & 26 & 28 & 23 & 26 & 29 \\
\hline $\mathrm{Ba}$ & 480 & 440 & & & & & & & & & & 498 \\
\hline $\mathrm{Sr}$ & 172 & 111 & 123 & 237 & 118 & 142 & 148 & 139 & 210 & 165 & 240 & 177 \\
\hline $\mathrm{Ga}$ & 15 & 18 & 21 & 13 & 13 & 14 & 16 & 11 & 15 & 18 & 16 & 18 \\
\hline $\mathrm{Nb}$ & 9 & 10 & 6 & 4 & 6 & 5 & 8 & 7 & 4 & 5 & 5 & 7 \\
\hline $\mathrm{Y}$ & 35 & 21 & 32 & 16 & 25 & 21 & 19 & 15 & 19 & 24 & 13 & 37 \\
\hline $\mathrm{Zr}$ & 62 & 81 & 115 & 101 & 112 & 96 & 111 & 83 & 118 & 113 & 47 & 131 \\
\hline $\mathrm{La}$ & 19.0 & 23.0 & & & & & & & & & & \\
\hline $\mathrm{Ce}$ & 39.0 & 48.0 & & & & & & & & & & \\
\hline $\operatorname{Pr}$ & 4.8 & 4.9 & & & & & & & & & & \\
\hline $\mathrm{Nd}$ & 19.0 & 20.0 & & & & & & & & & & \\
\hline $\mathrm{Sm}$ & 4.2 & 4.1 & & & & & & & & & & \\
\hline $\mathrm{Eu}$ & 1.5 & 1.1 & & & & & & & & & & \\
\hline $\mathrm{Gd}$ & 4.6 & 4.1 & & & & & & & & & & \\
\hline Dy & 5.6 & 4.6 & & & & & & & & & & \\
\hline Ho & 1.2 & 1.0 & & & & & & & & & & \\
\hline Er & 3.2 & 2.6 & & & & & & & & & & \\
\hline $\mathrm{Yb}$ & 3.9 & 2.7 & & & & & & & & & & \\
\hline $\mathrm{Lu}$ & 0.5 & 0.4 & & & & & & & & & & \\
\hline
\end{tabular}


Continued

\begin{tabular}{|c|c|c|c|c|c|c|c|c|c|c|c|c|c|}
\hline CG54 & PL21 & PL2 & PL3 & PL4 & PL5 & PL6 & PL7 & PL8 & PL9 & CG59 & CG60 & CG66 & KU1 \\
\hline 52.32 & 49.04 & 55.02 & 53.15 & 53.80 & 54.14 & 50.12 & 57.13 & 53.55 & 55.22 & 58.62 & 58.66 & 58.71 & 51.32 \\
\hline 0.57 & 0.61 & 1.17 & 0.92 & 0.35 & 1.36 & 0.68 & 1.70 & 0.65 & 1.42 & 0.44 & 0.48 & 0.54 & 0.90 \\
\hline 15.29 & 13.83 & 12.12 & 14.96 & 14.30 & 12.22 & 11.55 & 12.07 & 15.01 & 18.60 & 15.18 & 14.08 & 14.91 & 14.30 \\
\hline 8.59 & 9.00 & 9.00 & 10.96 & 9.45 & 10.08 & 9.03 & 11.63 & 5.65 & 10.45 & 10.39 & 12.54 & 10.48 & 11.88 \\
\hline 7.42 & 6.08 & 6.08 & 5.06 & 5.15 & 4.23 & 4.11 & 2.26 & 5.12 & 0.19 & 4.31 & 3.99 & 4.56 & 2.82 \\
\hline 4.44 & 6.86 & 6.86 & 2.69 & 4.46 & 3.54 & 8.51 & 4.70 & 6.64 & 4.00 & 2.58 & 1.68 & 2.98 & 5.96 \\
\hline 2.29 & 3.96 & 3.96 & 3.23 & 4.17 & 4.70 & 3.35 & 2.94 & 3.87 & 2.61 & 1.91 & 2 & 1.96 & 2.42 \\
\hline 0.91 & 1.87 & 1.87 & 3.09 & 1.16 & 3.70 & 3.80 & 3.60 & 2.22 & 3.41 & 3.26 & 2.75 & 3.5 & 1.72 \\
\hline 0.06 & 0.09 & 0.09 & 0.02 & 0.40 & 0.02 & 0.05 & 0.01 & 0.09 & 0.03 & 0.11 & 0.13 & 0.12 & 1.72 \\
\hline 5.09 & 8.94 & 8.94 & 5.91 & 6.37 & 6.00 & 8.78 & 4.01 & 7.18 & 5.93 & 3.19 & 3.69 & 2.25 & 8.42 \\
\hline 99.98 & 99.99 & 99.98 & 99.97 & 100.01 & 99.99 & 99.98 & 100.0 & 99.98 & 100.0 & 99.99 & 100.0 & 100.01 & 99.95 \\
\hline 124 & 76 & 101 & 45 & 35 & 63 & 18 & 41 & 98 & 85 & 464 & 342 & 312 & 414 \\
\hline 330 & 335 & 482 & 147 & 145 & 486 & 55 & 123 & 254 & 236 & 1663 & 1141 & 923 & 1004 \\
\hline 20 & 10 & 8 & 7 & 25 & 42 & 51 & 9 & 8 & 6 & 6 & 9 & 6 & 5 \\
\hline 141 & 78 & 73 & 86 & 71 & 48 & 112 & 93 & 45 & 98 & 74 & 78 & 81 & 93 \\
\hline 4 & 5 & & & & & & & & & 19 & 14 & 17 & 11 \\
\hline 81 & 121 & & & & 111 & 112 & 112 & & 38 & 71 & 72 & 100 & 86 \\
\hline 21 & 23 & 25 & & 19 & 11 & 16 & 12 & 20 & 22 & 121 & 96 & 130 & 110 \\
\hline 355 & & & & & & & & & & 519 & 508 & 720 & 627 \\
\hline 96 & 120 & 114 & 210 & 86 & 118 & 121 & 79 & 96 & 123 & 110 & 56 & 143 & 63 \\
\hline 13 & 12 & & & 9 & & & 11 & & & 18 & 15 & 15 & 189 \\
\hline 4 & 7 & 8 & 7 & 4 & 3 & 7 & 5 & 8 & 4 & 11 & 12 & 11 & 13 \\
\hline 9 & 36 & 25 & 24 & 16 & 23 & 24 & 18 & 21 & 11 & 15 & 12 & 15 & 16 \\
\hline \multirow[t]{14}{*}{44} & 114 & 120 & 109 & 68 & 59 & 110 & 96 & 75 & 81 & 79 & 101 & 108 & 90 \\
\hline & & & & & & & & & & 24.0 & 18.0 & 36.0 & \\
\hline & & & & & & & & & & 47.0 & 29.0 & 64.0 & \\
\hline & & & & & & & & & & 4.7 & 2.8 & 6.3 & \\
\hline & & & & & & & & & & 18.0 & 11.0 & 25.0 & \\
\hline & & & & & & & & & & 3.2 & 2.4 & 4.4 & \\
\hline & & & & & & & & & & 0.8 & 0.6 & 1.1 & \\
\hline & & & & & & & & & & 2.9 & 2.0 & 3.8 & \\
\hline & & & & & & & & & & 2.7 & 2.4 & 2.9 & \\
\hline & & & & & & & & & & 0.7 & 0.6 & 0.5 & \\
\hline & & & & & & & & & & 1.5 & 1.6 & 1.8 & \\
\hline & & & & & & & & & & 1.0 & 2.1 & 1.6 & \\
\hline & & & & & & & & & & 0.2 & 0.2 & 0.2 & \\
\hline & & & & & & & & & & 1.9 & 2.7 & 2.9 & \\
\hline
\end{tabular}


Appendix 2. Bulk-rock chemical analyses for major (wt\%), trace (ppm) and rare earth elements of shales up to $\mathrm{Kr} 117$ and shaly from Kr 4 BIFs.

\begin{tabular}{|c|c|c|c|c|c|c|c|c|c|c|c|}
\hline Samples & $\mathrm{Kr} 58$ & Kr 59 & $\mathrm{Kr} 88$ & Kr 32 & $\mathrm{Kr} 33 \mathrm{a}$ & Kr 117 & Kr 118 & $\mathrm{Kr} 4$ & $\mathrm{Kr} 7$ & $\mathrm{Kr} 71$ & $\mathrm{Kr} 120$ \\
\hline \multicolumn{12}{|l|}{$\mathrm{wt} \%$} \\
\hline $\mathrm{SiO}_{2}$ & 61.82 & 75.25 & 63.51 & 45.76 & 42.25 & 59.51 & 67.45 & 39.28 & 46.19 & 40.87 & 73.31 \\
\hline $\mathrm{TiO}_{2}$ & 0.93 & 0.98 & 0.73 & 2.47 & 0.37 & 2.73 & 0.79 & 0.28 & 0.29 & 0.20 & 0.15 \\
\hline $\mathrm{Al}_{2} \mathrm{O}_{3}$ & 16.14 & 11.18 & 16.95 & 16.53 & 10.62 & 14.95 & 13.95 & 5.79 & 10.13 & 5.67 & 5.47 \\
\hline $\mathrm{Fe}_{2} \mathrm{O}_{3}$ & 14.44 & 10.93 & 10.67 & 27.67 & 29.02 & 12.67 & 11.67 & 49.61 & 29.27 & 39.96 & 16.03 \\
\hline $\mathrm{MgO}$ & 2.67 & 0.31 & 2.89 & 1.06 & 5.32 & 2.09 & 1.89 & 6.04 & 6.11 & 6.12 & 2.19 \\
\hline $\mathrm{CaO}$ & 0.06 & 0.58 & 0.15 & 0.16 & 0.15 & 1.15 & 0.15 & 0.17 & 0.17 & 0.13 & 0.09 \\
\hline $\mathrm{Na}_{2} \mathrm{O}$ & $<0.2$ & $<0.2$ & $<0.2$ & $<0.2$ & $<0.2$ & $<0.2$ & $<0.2$ & $<0.2$ & $<0.2$ & $<0.2$ & $<0.2$ \\
\hline $\mathrm{K}_{2} \mathrm{O}$ & 1.4 & 0.76 & 3.29 & 3.79 & 0.21 & 3.29 & 2.29 & 2.29 & $<0.05$ & 0.14 & 0.24 \\
\hline $\mathrm{P}_{2} \mathrm{O} 5$ & 0.09 & 0.11 & 0.12 & 0.10 & 0.08 & 0.92 & 0.12 & 0.12 & 0.02 & 0.03 & 0.01 \\
\hline LOI $\%$ & 1.50 & 1.01 & 1.67 & 2.43 & 11.40 & 3.67 & 1.67 & 1.67 & 7.50 & 6.85 & 0.92 \\
\hline $\begin{array}{l}\text { Total } \\
\text { ppm }\end{array}$ & 99.97 & 101.1 & 99.98 & 99.99 & 101.10 & 99.98 & 99.98 & 99.98 & 99.81 & 99.97 & 99.48 \\
\hline $\mathrm{Cr}$ & $<30$ & 8 & $<30$ & $<30$ & 175 & $<30$ & $<30$ & $<30$ & $<30$ & $<30$ & $<30$ \\
\hline $\mathrm{Ni}$ & $<12$ & 9 & 717 & $<12$ & 637 & 19 & 18 & $<12$ & $<12$ & 4 & 538 \\
\hline Co & $<10$ & 11 & $<10$ & 18 & $<10$ & 48 & 11 & $<10$ & 10 & $<10$ & 7 \\
\hline $\mathrm{Zn}$ & 176 & 23 & 16 & 36 & 1 & 11 & 18 & 40 & 23 & 20 & 8 \\
\hline W & 88 & 29 & 21 & 31 & 29 & 17 & 29 & 71 & 72 & 101 & 27 \\
\hline $\mathrm{Rb}$ & 48 & 98 & 86 & 185 & 18 & 56 & 75 & 17 & 5 & 412 & 21 \\
\hline $\mathrm{Ba}$ & 45 & 25.8 & 101 & 341 & 29 & 221 & 148 & 17 & 11 & 199 & 17 \\
\hline $\mathrm{Ga}$ & 21 & $<3$ & 16 & 14 & 19 & 4 & 5 & 7 & 9 & 7 & 4 \\
\hline $\mathrm{Cu}$ & $<10$ & 18 & 33 & 7 & 8 & 16 & 21 & $<10$ & $<10$ & $<10$ & 23 \\
\hline $\mathrm{Rb}$ & 48 & 98 & 86 & 185 & 18 & 56 & 75 & 17 & 5 & 412 & 21 \\
\hline $\mathrm{Sr}$ & 81 & 9 & 2 & 6 & 11 & 3 & 18 & 10 & 2 & 10 & 51 \\
\hline V & 38 & 48 & 71 & 69 & 135 & 51 & 66 & 69 & 50 & 30 & 26 \\
\hline $\mathrm{Y}$ & 22 & 25 & 27 & 26 & 40 & 6 & 11 & 16 & 11 & 4 & 9 \\
\hline $\mathrm{Zr}$ & 7 & 16 & 13 & 12 & 4 & 9 & 59 & 55 & 43 & 38 & 31 \\
\hline $\mathrm{U}$ & $<5$ & 5 & $<5$ & 6 & $<5$ & 5 & $<5$ & 5 & $<5$ & $<5$ & 27 \\
\hline $\mathrm{Hf}$ & & & & 2.5 & 0.3 & & & & 1.4 & & \\
\hline $\mathrm{La}$ & & & & 34.0 & 6.5 & & & & 10.0 & & \\
\hline $\mathrm{Ce}$ & & & & 63.0 & 14.0 & & & & 26.0 & & \\
\hline $\operatorname{Pr}$ & & & & 64 & 1.1 & & & & 2.4 & & \\
\hline $\mathrm{Nd}$ & & & & 24.0 & 6.0 & & & & 11.0 & & \\
\hline $\mathrm{Sm}$ & & & & 3,7 & 1.2 & & & & 1.3 & & \\
\hline $\mathrm{Eu}$ & & & & 1.3 & O.4 & & & & 0.5 & & \\
\hline $\mathrm{Gd}$ & & & & 3.2 & 1,1 & & & & 1.2 & & \\
\hline Dy & & & & 2.7 & 1.1 & & & & 0.7 & & \\
\hline Ho & & & & 05 & 0.2 & & & & 0.1 & & \\
\hline $\mathrm{Er}$ & & & & 1.3 & 0.5 & & & & 0.4 & & \\
\hline $\mathrm{Yb}$ & & & & 1.3 & 0.5 & & & & 0.5 & & \\
\hline $\mathrm{Lu}$ & & & & 0.2 & 0.1 & & & & 0.1 & & \\
\hline
\end{tabular}


Appendix 3. Bulk-rock chemical analyses for major (wt\%), trace (ppm) and rare earth elements of alkali-alterated BIFs.

\begin{tabular}{|c|c|c|c|c|c|c|c|c|c|c|c|}
\hline Samples & $\mathrm{Kr} 2$ & $\operatorname{Kr} 19 a$ & $\mathrm{Kr} 23$ & $\mathrm{Kr} 24$ & $\mathrm{Kr} 25$ & $\mathrm{Kr} 26$ & Kr 34 & $\mathrm{Kr} 70$ & $\mathrm{Kr} 76$ & $\operatorname{Kr} 130$ & Kr 163 \\
\hline \multicolumn{12}{|l|}{ (wt \%) } \\
\hline $\mathrm{SiO}_{2}$ & 40.12 & 45.80 & 36.60 & 29.04 & 53.71 & 62.52 & 39.02 & 27.27 & 57.53 & 49.80 & 47.79 \\
\hline $\mathrm{TiO}_{2}$ & 0.08 & $<0.04$ & 0.03 & $<0.03$ & $<0.03$ & $<0.03$ & 0.09 & 0.04 & $<0.03$ & 0.04 & $<0.03$ \\
\hline $\mathrm{Al}_{2} \mathrm{O}_{3}$ & 0.48 & 0.25 & 0.10 & 0.03 & 0.56 & 0.02 & 0.25 & $<0.1$ & $<0.1$ & $<0.1$ & $<0.1$ \\
\hline $\mathrm{Fe}_{2} \mathrm{O}_{3}$ & 46.04 & 42.94 & 55.97 & 59.16 & 37.11 & 29.89 & 40.87 & 64.21 & 31.45 & 42.94 & 46.93 \\
\hline $\mathrm{MgO}$ & 4.87 & 2.73 & 3.51 & 2.40 & 1.79 & 1.71 & 2.47 & 2.20 & 1.12 & 3.03 & 0.74 \\
\hline $\mathrm{CaO}$ & 2.85 & 0.49 & 0.94 & 2.11 & 1.39 & 1.26 & 4.56 & 0.80 & 0.37 & 0.49 & 0.49 \\
\hline $\mathrm{Na}_{2} \mathrm{O}$ & 1.59 & 7.31 & 1.82 & 3.71 & 4.42 & 5.01 & 7.43 & .35 & 7.89 & 3.01 & 3.32 \\
\hline $\mathrm{K}_{2} \mathrm{O}$ & 3.36 & $<0.25$ & 0.07 & 0.05 & $<0.05$ & 2.39 & $<0.05$ & $<0.05$ & 0.34 & $<0.05$ & $<0.05$ \\
\hline $\mathrm{P}_{2} \mathrm{O}_{5}$ & 0.129 & 0.07 & 0.11 & 0.53 & 0.38 & 0.18 & 0.07 & 0.06 & $<0.05$ & $<0.05$ & 0.05 \\
\hline LOI\% & 1.19 & 0.98 & 0.95 & 3.09 & 1.55 & 1.10 & 4.30 & 0.30 & 0.81 & 0.98 & 0.80 \\
\hline Total & 100.1 & 100.08 & 100.17 & 100.09 & 100.45 & 100.06 & 99.08 & 100.17 & 99.55 & 100.02 & 99.88 \\
\hline \multicolumn{12}{|l|}{$\mathrm{ppm}$} \\
\hline $\mathrm{Cr}$ & 1 & 182 & 6 & 9 & 144 & 404 & 11 & 7 & 115 & 782 & 602 \\
\hline $\mathrm{Ni}$ & 47 & 320 & 17 & $<12$ & 265 & 403 & $<12$ & 48 & 454 & 580 & 320 \\
\hline Co & 2 & $<10$ & $<10$ & 18 & 1 & 7 & $<10$ & 6 & 8 & $<10$ & $<10$ \\
\hline $\mathrm{Zn}$ & $<40$ & 6 & 31 & 25 & 17 & $<40$ & 30 & 72 & $<40$ & 16 & 28 \\
\hline W & 105 & 47 & 193 & 152 & 32 & 24 & 104 & 259 & 39 & 67 & 21 \\
\hline $\mathrm{Rb}$ & 16 & 5 & 18 & 7 & 6 & 123 & 6 & 11 & 34 & 5 & 8 \\
\hline $\mathrm{Ba}$ & 82 & 14 & 18 & 19 & 31 & 110 & 27 & 94 & 15 & 24 & 11 \\
\hline $\mathrm{Ga}$ & 21 & 5 & 19 & $<3$ & 3 & $<3$ & 6 & 15 & 30 & $<3$ & $<3$ \\
\hline $\mathrm{Cu}$ & $<10$ & $<10$ & 2 & $<10$ & 4 & $<10$ & $<10$ & $<10$ & 62 & 3 & $<10$ \\
\hline $\mathrm{Rb}$ & 16 & 5 & 18 & 7 & 6 & 123 & 6 & 11 & 34 & 5 & 8 \\
\hline $\mathrm{Sr}$ & 16 & 3 & 18 & 51 & 14 & 11 & 44 & 19 & 5 & 3 & 1 \\
\hline $\mathrm{V}$ & 10 & 8 & 252 & 142 & 18 & 10 & 8 & 211 & 12 & 9 & 21 \\
\hline $\mathrm{Y}$ & 17 & 26 & 24 & 27 & 19 & 13 & 8 & 13 & 1 & 6 & 26 \\
\hline $\mathrm{Zr}$ & 29 & 9 & 232 & 89 & 6 & 10 & 1387 & 123 & 76 & 18 & 21 \\
\hline $\mathrm{U}$ & $<5$ & $<5$ & 12 & 10 & 3 & $<5$ & 7 & $<5$ & $<5$ & 3 & 6 \\
\hline $\mathrm{Hf}$ & & & & & 0.4 & 0.5 & & & 0.2 & & \\
\hline $\mathrm{La}$ & & & & & $<0.2$ & 0.3 & & & 02 & & \\
\hline $\mathrm{Ce}$ & & & & & 4.3 & 5.2 & & & 4.3 & & \\
\hline $\operatorname{Pr}$ & & & & & 0.3 & 0.5 & & & 0.4 & & \\
\hline $\mathrm{Nd}$ & & & & & 2.1 & 3.1 & & & 1.4 & & \\
\hline $\mathrm{Sm}$ & & & & & 0.8 & 1.0 & & & 0.4 & & \\
\hline $\mathrm{Eu}$ & & & & & 0.6 & 0.6 & & & 0.2 & & \\
\hline $\mathrm{Gd}$ & & & & & 0.1 & 1.1 & & & 0.4 & & \\
\hline Dy & & & & & 1.3 & 1.1 & & & 0.3 & & \\
\hline Но & & & & & 0.4 & 0.2 & & & 0.1 & & \\
\hline Er & & & & & 0.8 & 0.5 & & & 0.3 & & \\
\hline $\mathrm{Yb}$ & & & & & 0.8 & 0.5 & & & 0.2 & & \\
\hline $\mathrm{Lu}$ & & & & & 0.1 & 0.1 & & & 0.5 & & \\
\hline
\end{tabular}


Appendix 4. Bulk-rock chemical analyses for major (wt\%), trace (ppm) and rare earth elements of cherts and cherty BIFs.

\begin{tabular}{|c|c|c|c|c|c|c|c|c|c|c|}
\hline Samples & $\mathrm{Kr} 1$ & $\mathrm{Kr} 3$ & $\operatorname{Kr} 5$ & $\mathrm{Kr} 6$ & Kr 27 & $\mathrm{Kr} 28$ & $\mathrm{Kr} 98$ & $\mathrm{Kr} 8$ & Kr 17 & Kr 29 \\
\hline \multicolumn{11}{|l|}{ (wt \%) } \\
\hline $\mathrm{SiO}_{2}$ & 73.31 & 56.40 & 50.38 & 57.29 & 69.71 & 62.72 & 74.93 & 42.26 & 47.18 & 47.81 \\
\hline $\mathrm{TiO}_{2}$ & 0.15 & $<0.03$ & 0.13 & $<0.03$ & $<0.03$ & $<0.03$ & $<0.03$ & 0.03 & $<0.03$ & $<0.03$ \\
\hline $\mathrm{Al}_{2} \mathrm{O}_{3}$ & 0.47 & $<0.1$ & 0.73 & 0.32 & $<0.1$ & 0.48 & $<0.1$ & 0.89 & 0.2 & 0.31 \\
\hline $\mathrm{Fe}_{2} \mathrm{O}_{3}$ & 18.64 & 38.01 & 42.16 & 31.56 & 22.07 & 31.98 & 15.34 & 51.45 & 48.17 & 40.89 \\
\hline $\mathrm{MgO}$ & 2.19 & $<0.1$ & $<0.1$ & 2.04 & 1.87 & 0.76 & 2.11 & 2.03 & 1.63 & 1.74 \\
\hline $\mathrm{CaO}$ & $<0.1$ & 0.93 & $<0.1$ & 0.48 & 0.59 & 0.75 & 1.33 & 0.50 & 1.08 & 1.23 \\
\hline $\mathrm{Na}_{2} \mathrm{O}$ & $<0.20$ & $<0.2$ & $<0.2$ & $<0.2$ & 0.33 & $<0.2$ & $<0.2$ & $<0.2$ & $<0.2$ & $<0.2$ \\
\hline $\mathrm{K}_{2} \mathrm{O}$ & 0.74 & $<0.05$ & $<0.05$ & 0.10 & $<0.05$ & 0.19 & $<0,05$ & 0.35 & $<0.05$ & 0.19 \\
\hline $\mathrm{P}_{2} \mathrm{O}_{5}$ & $<0.05$ & $<0.05$ & 0.07 & 0.12 & 0.12 & 0.10 & $<0.05$ & 0.08 & $<0.05$ & 0.03 \\
\hline LOI\% & 4.48 & 4.66 & 6.55 & 8.10 & 5.31 & 3.04 & 6.30 & 2.35 & 1.73 & 5.83 \\
\hline Total & 99.98 & 100.00 & 100.02 & 100.01 & 100.00 & 100.02 & 100.01 & 99.99 & 99.99 & 100.00 \\
\hline \multicolumn{11}{|l|}{ ppm } \\
\hline $\mathrm{Cr}$ & 90 & 104 & 18 & 26 & 24 & 150 & 163 & 404 & 3 & 204 \\
\hline $\mathrm{Ni}$ & 115 & 107 & $<12$ & 194 & 152 & 204 & $<12$ & 112 & $<12$ & $<12$ \\
\hline Co & 5 & 4 & 19 & 12 & $<10$ & $<10$ & 52 & $<10$ & 6 & 19 \\
\hline $\mathrm{Zn}$ & 8 & 5 & 2 & 3 & 1 & 3 & 2 & 6 & $<10$ & 1 \\
\hline W & 27 & 83 & 370 & 610 & 62 & 43 & 407 & 60 & 353 & 62 \\
\hline $\mathrm{Ba}$ & 17 & 11 & 11 & 13 & 16 & 55 & 14 & 35 & 25 & 36 \\
\hline $\mathrm{Ga}$ & 4 & 11 & $<3$ & 3 & 4 & 6 & 1 & 4 & $<3$ & 5 \\
\hline $\mathrm{Cu}$ & $<10$ & 2 & $<10$ & 2 & 3 & $<10$ & $<10$ & $<10$ & 2 & $<10$ \\
\hline $\mathrm{Rb}$ & 21 & 2 & 5 & 6 & 12 & 16 & 3 & 37 & 7 & 14 \\
\hline $\mathrm{Sr}$ & 51 & $<10$ & 2 & 3 & 5 & 6 & 12 & 19 & 21 & 14 \\
\hline V & 26 & 19 & 8 & 15 & 2 & 23 & 5 & 14 & 11 & 19 \\
\hline $\mathrm{Y}$ & 29 & 13 & 36 & 38 & 16 & 27 & 37 & 12 & 17 & 9 \\
\hline $\mathrm{Zr}$ & 11 & 1 & 1 & 4 & 2 & 3 & 1 & 5 & 3 & 2 \\
\hline $\mathrm{U}$ & 17 & $<5$ & 2 & $<5$ & $<5$ & 2 & 2 & $<5$ & $<5$ & 1 \\
\hline $\mathrm{Hf}$ & & & & & & $<0.1$ & & & & \\
\hline $\mathrm{La}$ & & & & & & $<0.2$ & & & & \\
\hline $\mathrm{Ce}$ & & & & & & 2.00 & & & & \\
\hline $\operatorname{Pr}$ & & & & & & $<0.1$ & & & & \\
\hline $\mathrm{Nd}$ & & & & & & $<0.5$ & & & & \\
\hline $\mathrm{Sm}$ & & & & & & 0.2 & & & & \\
\hline $\mathrm{Eu}$ & & & & & & 0.1 & & & & \\
\hline $\mathrm{Gd}$ & & & & & & 0.6 & & & & \\
\hline Dy & & & & & & 0.6 & & & & \\
\hline Ho & & & & & & 0.2 & & & & \\
\hline $\mathrm{Er}$ & & & & & & 0.6 & & & & \\
\hline $\mathrm{Yb}$ & & & & & & 0.8 & & & & \\
\hline $\mathrm{Lu}$ & & & & & & 0.2 & & & & \\
\hline
\end{tabular}


Continued

\begin{tabular}{|c|c|c|c|c|c|c|c|c|c|}
\hline $\mathrm{Kr} 33$ & $\mathrm{Kr} 69$ & Kr 92 & $\mathrm{Kr} 93$ & $\mathrm{Kr} 95$ & Kr 99 & Kr 100 & Kr 101 & Kr 103 & Kr 106 \\
\hline 48.91 & 38.77 & 49.22 & 42.01 & 48.93 & 48.83 & 50.88 & 49.36 & 50.78 & 49.40 \\
\hline 0.05 & $<0.03$ & 0.04 & 0.04 & 0.05 & $<0.03$ & $<0.03$ & $<0.03$ & $<0.03$ & $<0.03$ \\
\hline 1.87 & 0.15 & 0.83 & 0.81 & 0.19 & 0.73 & 0.44 & 0.20 & 0.44 & 0.48 \\
\hline 34.97 & 58.09 & 37.22 & 41.50 & 45.31 & 39.84 & 37.26 & 38.01 & 37.22 & 39.90 \\
\hline 4.09 & 1.52 & 2.61 & 3.65 & 1.46 & 2.05 & 2.47 & 2.47 & 2.47 & 3.76 \\
\hline 2.68 & 0.24 & 0.71 & 2.38 & 1.84 & 1.89 & 0.56 & 0.56 & 0.58 & 0.75 \\
\hline$<0.2$ & 0.28 & $<0.2$ & $<0.2$ & 0.20 & 0.63 & $<0.2$ & $<0.2$ & $<0.2$ & $<0.2$ \\
\hline 0.20 & 0.14 & 0.87 & 1.13 & 0.83 & 0.42 & 0.34 & 0.17 & 0.33 & 0.19 \\
\hline 0.07 & 0.10 & $<0.05$ & 0.08 & 0.42 & 0.32 & 0.04 & 0.04 & 0.03 & 0.10 \\
\hline 7.15 & 1.45 & 8.40 & 8.33 & 0.79 & 5.28 & 8.01 & 9.52 & 8.14 & 5.43 \\
\hline 99.99 & 100.00 & 100.01 & 100.01 & 100.02 & 99.99 & 100.00 & 100.00 & 99.99 & 100.01 \\
\hline 558 & 77 & 182 & 227 & 135 & 7 & 63 & 298 & 31 & 550 \\
\hline 650 & 318 & 215 & 17 & $<12$ & $<12$ & $<12$ & $<12$ & $<12$ & 404 \\
\hline 3 & 60 & 17 & 14 & $<10$ & 25 & 5 & $<10$ & 15 & $<10$ \\
\hline 2 & 1 & 1 & 2 & $<40$ & 13 & 2 & $<40$ & $<40$ & 3 \\
\hline 37 & 948 & 202 & 162 & 74 & 381 & 219 & 35 & 279 & 43 \\
\hline 70 & 413 & 70 & 87 & 40 & 58 & 8 & 14 & 32 & 55 \\
\hline 2 & 12 & 13 & 3 & 10 & 10 & $<3$ & 4 & 3 & $<3$ \\
\hline$<10$ & $<10$ & 5 & $<10$ & $<10$ & 5 & 4 & $<10$ & $<10$ & $<10$ \\
\hline 15 & $<42$ & 122 & 189 & 117 & 35 & 36 & 23 & 40 & 16 \\
\hline 10 & 19 & 4 & 10 & 87 & 31 & 6 & 11 & 8 & 6 \\
\hline 11 & 7 & 10 & 2 & 3 & 2 & 6 & 2 & 4 & 3 \\
\hline 38 & 13 & 13 & 3 & 12 & 9 & 11 & 22 & 26 & 27 \\
\hline 5 & 3 & 5 & 7 & 4 & 2 & 3 & 4 & 3 & 3 \\
\hline \multirow[t]{14}{*}{$<5$} & $<5$ & $<5$ & $<5$ & $<5$ & $<5$ & 1 & 2 & $<5$ & $<5$ \\
\hline & & 0.2 & & & 0.2 & 0.2 & 0.1 & 0.2 & $<0.1$ \\
\hline & & 0.2 & & & $<0.2$ & 0.2 & $<2.0$ & $<0.2$ & 0.8 \\
\hline & & 3.8 & & & 3.0 & 4.1 & 2.6 & 4.3 & 5.0 \\
\hline & & 0.3 & & & $<0.1$ & 0.3 & $<0.1$ & 0.4 & 0.1 \\
\hline & & 0.9 & & & 0.8 & 1.3 & 0.8 & 1.2 & 1.6 \\
\hline & & 0.2 & & & 0.1 & 0.3 & 0.2 & 0.2 & 0.5 \\
\hline & & 0.1 & & & 0.1 & 0.2 & 0.2 & 0.1 & 0.3 \\
\hline & & 0.2 & & & 0.1 & 0.3 & $<0.1$ & 0.2 & $<0.1$ \\
\hline & & 0.2 & & & 0.1 & 0.2 & 0.3 & 0.2 & 0.3 \\
\hline & & $<0.1$ & & & 0.1 & 0.1 & 0.1 & 0.1 & 0.1 \\
\hline & & 0.2 & & & 0.1 & 0.2 & 0.2 & 0.1 & 0.2 \\
\hline & & 0.1 & & & $<0.1$ & 0.1 & $<0.1$ & $<0.1$ & $<0.1$ \\
\hline & & $<0.1$ & & & $<0.1$ & $<0.1$ & $<0.1$ & $<0.1$ & $<0.1$ \\
\hline
\end{tabular}

